\title{
Improving Speaking Skill Through Speaking Club Viewed from Students' Perception
}

\author{
Wahyuniati \\ English Teacher Education Department \\ State Islamic University of Sunan Ampel
}

\author{
Nadhifatul Maulidiyah \\ Faculty of Education \\ UIN Sunan Ampel Surabaya \\ Nadhifasamsu176@gmail.com
}

\author{
Marina Qolbia \\ Faculty of Education \\ UIN Sunan Ampel Surabaya \\ Marinamq12@gmail.com
}

\begin{abstract}
Speaking is a complex skill that its components must be mastered by students, including grammar, vocabulary, fluency, comprehension, pronunciation. So, it is hard to achieve by most EFL learners. This study aims to identify if the speaking club improves the student speaking skill or not. The subject of this study was the students who join English speaking club in English Education Department in UIN Sunan Ampel Surabaya by 10 students. The research design used qualitative descriptive. To collect the data, the writer used questionnaires distributed to the students through Google form. The result of this study indicated that most of the students who join speaking club have good speaking improvement in their speaking English, such as improvement of pronunciation, vocabulary, and fluency in speaking English.
\end{abstract}

Keywords: speaking club, speaking skill, speaking improvement

\section{INTRODUCTION}

One of the significant aspects of communication, particularly in foreign language is speaking ability. As a human being, people always interact with others in fulfilling their daily needs. In this case, they communicate with one another. People commonly express and communicate their willingness, feelings, ideas, and thoughts to others through speaking. Mulya (2013) suggested that someone can deliver his or her information and ideas and keep his or her social relationship by communicating with others through speaking. Brown (2001) stated that speaking is an interactive process constructing meaning that involves producing, receiving, and processing information. Additionally, Afrizal (2015) argues that speaking is a process which is interactive to make and receive information.

In the context of learning English, speaking is a complex skill which involves an interaction between the speaker and the listener in an active process. There are several essential components of speaking skills proposed by Brown (2004) consisting of components: grammar, vocabulary, fluency, comprehension, pronunciation and task. Those components are the whole package that affects the ability of students speaking skill. Even Those components are commonly used to check the ability of students speaking skill. While Weir (2008) stated that there are five components to check the speaking skill, they are accuracy, appropriateness, adequacy of vocabulary, grammatical accuracy, intelligibility, fluency, and relevance of content. Thus, the students have to master the entire components to achieve the aim of speaking skill andtobe communicated.

Unfortunately, the ability to speak is hard to achieve by most English foreign learners. They are generally afraid of making a mistake. First, students often have incorrect pronunciation. Second, students have a lack of confidence to share their opinions and ideas. They are also afraid of making a mistake in their performance. A study by Hadriana (2008) found that there are several problems faced by students in speaking, for example: feeling afraid of making grammatical errors in their speech, uncomfortable feeling in pronouncing the words or sentences, and lack of vocabulary. However, in curriculum 2013, speaking is one of the skills that have to be mastered by students for each level. Allocation of time to study English is very limited. Students only have about 90 minutes to study English every week. It is not enough time to improve their English skills, especially in speaking skills. An alternative to encourage students to be more active in speaking practices is through programs outside the class, such as speaking club. Moreover, Katleen (2016) argues that speaking club offers creative opportunities for communities to experiment and play with language and to practise using English in an atmosphere that is supportive, encouraging and respectful.

In addition, previous studies have focused on several issues related to speaking club as media to learn English. A study by Selvia (2015) investigated the effect of English club on students' speaking ability. The findings informed that English Club gives positive effects for students. The students have better speaking ability than students those who do not. The differences between students who join in English club program and who do not join to this program are the students who join in English club program have good speaking ability both in grammar, vocabulary and pronunciation. Another previous study by Aida Yuliandasari and Wendi Kusriandi (2015) also investigated students' perception of English club extracurricular in speaking practices at Madrasah. The result revealed that students' respond is in high category frequency with high 
percentage reaches. It means students have perception positively to English club activity. Then, the result of the test of research indicates that English club has a good effect. The average of students score showed that students could do their best in speaking.

Despite the interest, a few research studies both strengths and weaknesses in joining speaking club and its impact on a certain skill within speaking. Considering this problem, the researcher tries to find out what are speaking skills dominated by students after joining speaking club and how do the students perceive speaking club improve their speaking skills. Thus this research conducts people's opinion about what the strengths and weaknesses faced by students in speaking club. Then, the limitation of this research is only to investigate students who are the member of speaking club. This study also provides consideration whether speaking club can be an alternative and effective way to improve speaking fluency outside the class.

\section{LITERATURE REVIEW}

This chapter explains the theoretical framework which consists of the definition of speaking, the purpose of speaking, the aspect of speaking fluency, definition of speaking club, and previous study.

\section{A. EFL Speaking Skills}

Speaking skill is also one of the hardest skills which must be implemented in learning activity. There are several problems that cause the lack of student's ability in speaking, for example, the lack of confidence, vocabulary items, and less implementation of students speaking skill in learning activity. The students can improve their speaking skill by practising with their friends.

Speaking skill is considered as the main important skill that has to be mastered by the students, including grammar, vocabulary, fluency, comprehension, pronunciation, and task (Brown, 2004). Those are the components of speaking skill that must be mastered by students because they affect the students' ability in speaking. According to Weir (2008) stated that there are five components of speaking; accuracy, intelligibility, fluency, and relevance of content while those components have different meanings.

Grammar can influence successful human speech in communication. It refers to as functional which means that the learners make statements about the semantics and communication significance of particular points of grammar, how language use, the conveying of meaning or the maintenance of personal relation or the organization of discourse. So grammar helps speakers to use and more understand English language structure accurately and immediately, which facilitates their fluency (Richards \&Renandya, 2002).

Vocabulary is one of the most important aspects of foreign language. It can cause the students may not be confident to speak English when they are poor in vocabulary. To understand the meaning, the learner must have enough knowledge of words and sentence. It can be gotten from reading book, and often opening the dictionary. The speaker must select understandable and appropriate vocabulary to be spoken to the audience so that the audience can understand what you say.Then, usually, people who can use English well are fluent and accurate in speaking.

Fluency is the property of a person or of a system that delivers information quickly and with expertise. According to Ellis (2009) stated that fluency is the capacity to use language in real-time, to emphasize meanings, possibly drawing on more lexicalized system. Fluent speakers can express themselves appropriately and without hesitation and do not worry about making mistakes.

According to Baihaqi (2016), comprehension is the capacity of the main to perceive and understand and power to grasp the ideas. By having comprehension, it can avoid misunderstanding between speaker and audience while Pronunciation is the basic component in teaching and learning speaking. Therefore, the students know the differences between

written and spoken language. Pronunciation is also avoiding the students" errors in produce sound. The pronunciation can be included by vowels and consonants; and the stress and intonation.

According to Nunan (2005), task is a classroom activity which involves learners comprehending, manipulating, producing, and interacting in the target language. It engages the students to use the language communicatively or reflectively to get outcome rather than that of learning specified feature of the target language. The task must include the goals, input, activities, setting, teacher role, and learner role.

Accurate speakers will not make a mistake in grammar, vocabulary, and pronunciation. Accuracy is achieved to some extent by allowing students to focus on the elements of phonology, grammar and discourse in their spoken output while fluency may in many communicative language courses be an initial goal in language teaching. It can be concluded that accuracy is the ability to produce grammatically with correct grammar, vocabulary, and pronunciation (Spratt, Pulverness, William, 2005). Besides, the relevance of content also includes component speaking. It means that the content must be important so the audience can get the information correctly from the speaker.

\section{B. The Purpose of Speaking}

According to Tarigan (2013), People can master speaking skill by doing some practice and training. He also stated, there are three important purposes of speaking, such as:

To inform, through communication, people will inform their ideas or share their knowledge, thoughts, information to someone else.

To Entertain, people will express their feelings about happiness, sadness, or madness to someone else. So, it can build a mutual communication when they know how to entertain.

To Persuade, sometimes in a certain activity, people use speaking to persuade someone else.

From the statement above, productive speaking helps students to develop speaking skill, which is used in human life that has a purpose of informing, entertaining and persuading someone else. 


\section{Indonesia Students' Problem With Speaking English as Foreign Language}

Finding by Devi NovitaSwary(2014) stated that students have problems with speaking skill because of many cases. They are low of vocabulary mastering, limited of grammar knowledge and pronunciation, shyness, nervousness, fear of making mistakes, lack of confidence, limited of practice, minimum opportunities, environment factor, mother tongue used dominantly, low of motivation are the kinds of students" problems in learning English speaking. The researcher found that the ability of the students of SMP Negeri 1 Talaga was at low level. Most of the students cannot be able to speak by using English, although in a very simple phrase or sentences. There are only a few students who have good skill in English, especially in English speaking. According to Silvia Amita \& Lisa Tavriyanti (2015), students have a problem with speaking English because they are less self-confidence to speak in front of their friends. Some of them think that speaking is difficult. So the researcher thinks that students need an attractive activity to encourage the student to speak.

\section{Speaking Club as an Alternative to Practice Speaking}

English speaking club is defined as students" extra learning program besides regular English class, which more focuses on mastering skills of English in teaching and learning activities (Aida Yuliandasari\& Wendi Kusriandi, 2015). In English speaking club, the leader can initiate debate, games, sketch, poem, song, etc. English club is a real place where the learning of English is more practical (Mouleka 2013). It can be concluded that speaking club is a media to facilitate students in practising, increase and build about students' motivation to learn and practice speaking. Students could exchange, share their knowledge, and get new vocabulary and information among their friends. Students can share their difficulties in speaking practice and look forward to how to understand and solve their problems. Finally, the main goals and expectations about speaking club are as a media to improve students' speaking ability with a high self-confidence in speaking practice even though they still make some mistakes about grammatical rules.

Related to the present research, there was a previous study in a similar issue, Baihaqi (2016), conducted research, the influence of speaking club in improving students' speaking ability. The result of this study stated that the students' ability in speaking has improved after they joined the speaking club, and based on the questionnaire result, students provide a positive response towards the implementation of speaking club. Research done by Selvia Fitri Anggraeni (2016) showed that English club gives positive effects for students at SMP N 2 Lembah Gumanti. The students have a better speaking ability than students those who do not. Differences between students who join in English club program and who do not join this program are, the students who join in English Club program have speaking ability both in grammar, vocabulary and pronunciation.

This study has different aspects, and the first one is a set of participant. This research only takes a part of 5th semester students of State Islamic University of Sunan Ampel instead of taking all of the students. This research concern only in the fluency of speaking, while Baihaqi (2016) relates speaking club with pronunciation, grammar, vocabulary, and fluency. This research may discuss term pronunciation, grammar, vocabulary, and fluency. Because this study only concerns on fluency so that it may have a different result of the study.

\section{METHOD}

This research used descriptive qualitative which is concerning with qualitative phenomena, such as perception or interpret the condition of the present. According to Cresswell, J. (2012), a qualitative approach is a study that intends to understand phenomenon about what is experienced by research subject such as behaviour, perception, motivation, action and so on. The data is gotten from questionnaire. Brown (2001) stated that questionnaires are any written instruments that present respondents with a series of questions or statements which they are expected to react either by writing out the answers or selecting from among existing answer. So to collect

the data, the present study used questionnaire regarding students' perception toward improving speaking skills through speaking club. In the questionnaire, there are four scales of measurements. Those are strongly agree, agree, strongly disagree, disagree. The questionnaire consisted of 14 multiple choice questions by using English.

This study is limited to students who join the speaking club in English Education Department, State Islamic University of Sunan Ampel Surabaya. So, the questionnaire is distributed to students by google form. The researcher only sent the link of the questionnaire, and then the students directly answered it.

\section{FINDING AND DISCUSSION}

The data were obtained from the distribution of the questionnaire to the students. It was designed to help the writer to get more information about students perception about speaking club can improve speaking skill. In order to find out the percentage from all answer at every question, the writer used a percentage formula as in the following:

Table 1. Percentage and number of respondents according to responses

\begin{tabular}{|c|c|c|c|c|c|}
\hline No & Statement & $\begin{array}{l}\text { Strongly } \\
\text { Agree }\end{array}$ & Agree & $\begin{array}{l}\text { Strongly } \\
\text { Disagree }\end{array}$ & Disagree \\
\hline 1. & $\begin{array}{l}\text { Speaking environment } \\
\text { club is important for } \\
\text { me. }\end{array}$ & $45.5 \%$ & $54.5 \%$ & & \\
\hline 2. & $\begin{array}{lr}\text { Speaking club affects } \\
\text { my fluency } \\
\text { speaking. }\end{array}$ & $45.5 \%$ & $54.5 \%$ & & \\
\hline 3. & $\begin{array}{lr}\text { Speaking } & \text { club } \\
\text { improves } & \text { my } \\
\text { pronunciation } & \text { in } \\
\text { speaking. } & \\
\end{array}$ & $36.4 \%$ & $63.6 \%$ & & \\
\hline 4. & $\begin{array}{lr}\text { Speaking club affects } \\
\text { my accuracy } \\
\text { speaking. }\end{array}$ & $18.2 \%$ & $63.6 \%$ & & $18.2 \%$ \\
\hline
\end{tabular}




\begin{tabular}{|c|c|c|c|c|c|}
\hline 5. & $\begin{array}{l}\text { Speaking club } \\
\text { improves my grammar } \\
\text { understanding }\end{array}$ & $18.2 \%$ & $54,5 \%$ & $9.1 \%$ & $18.2 \%$ \\
\hline 6. & $\begin{array}{lr}\text { Speaking } & \text { club } \\
\text { increases } & \text { my } \\
\text { vocabulary mastery } & \end{array}$ & $54.5 \%$ & $45.5 \%$ & & \\
\hline 7. & $\begin{array}{l}\text { Speaking club reduce } \\
\text { my misunderstanding. }\end{array}$ & $18.2 \%$ & $72.7 \%$ & $9.1 \%$ & \\
\hline 8. & $\begin{array}{l}\text { Speaking club } \\
\text { activities increases my } \\
\text { confidence. }\end{array}$ & $45.5 \%$ & $54.5 \%$ & & \\
\hline 9. & $\begin{array}{l}\text { Speaking club impacts } \\
\text { my ability to exchange } \\
\text { the relevant idea. }\end{array}$ & $45.5 \%$ & $54.5 \%$ & & \\
\hline 10. & $\begin{array}{lrr}\begin{array}{l}\text { Speaking } \\
\text { efficient }\end{array} & \text { club } & \text { gives } \\
\text { exercise. } & & \text { speaking } \\
\end{array}$ & $18.2 \%$ & $72.7 \%$ & & $9.1 \%$ \\
\hline 11. & $\begin{array}{l}\text { Speaking club provides } \\
\text { supplementary } \\
\text { material such as } \\
\text { storybooks, language } \\
\text { CDs, etc. }\end{array}$ & $18.2 \%$ & $45.5 \%$ & & $36.4 \%$ \\
\hline 12. & $\begin{array}{l}\text { Speaking club provides } \\
\text { sufficiency facilities. }\end{array}$ & & $54.5 \%$ & $9.1 \%$ & $36.4 \%$ \\
\hline 13. & $\begin{array}{l}\text { I enjoy the speaking } \\
\text { environment club. }\end{array}$ & $27.3 \%$ & $72.7 \%$ & & \\
\hline 14. & $\begin{array}{l}\text { I am not afraid of } \\
\text { making mistakes in } \\
\text { this club. }\end{array}$ & $63.4 \%$ & $36.6 \%$ & & \\
\hline
\end{tabular}

For statement number 1 , it is about the importance of speaking environment club for the respondents. There are 6 respondents $(54.5 \%)$ who agree if the environment in speaking club is important to support their speaking skill. The rest, 5 respondents $(45.5 \%)$ strongly agree with this statement. Thus, it can be concluded that all of the students (11 students) agreed that speaking club is useful.

The second statement is the same as the previous statement. There are 6 respondents $(54.5 \%)$ who agree if speaking club affects their fluency in speaking. The rest, 5 respondents $(45.5 \%)$ strongly agree with this statement. On the other hand, there are no one who answer in disagree or strongly disagrees, it means that they believe that by joining speaking club will be improving their fluency in speaking English.

Speaking club can improve pronunciation in speaking for 4 respondents $(36.4 \%)$ which strongly agree with this statement, and 7 respondents $(63.6 \%)$ agree. Therefore, it could be assumed that joining speaking club can improve their pronunciation. No one disagrees or strongly disagree with this statement.

Related with statement number 4, speaking club affects respondents' accuracy in speaking. There are 7 respondents (63.6\%) who agree with this statement and 2 respondents (18.2\%) strongly agree and also the same respondents which disagree. This is different from the previous statement that all of the participants are in agreement. Maybe they who disagree with this statement still can not feel that joining speaking club can affect their accuracy.

For statement number 5, the respondents are filling all of the answers. There are 2 respondents $(18.2 \%)$ who strongly agree, 5 respondents $(54.5 \%)$ who agree, and only one respondent $(9.1 \%)$ who strongly disagree and the last 2 (18.2\%) who disagree. Some of them may not feel some improvement during joining speaking club in their grammar understanding.

Contrarily, in increasing vocabulary mastery, speaking club was thought by 6 respondents $(54.5 \%)$ which strongly agree with this statement and the rest, 5 respondents $(45.5 \%)$ agree. No doubt in their mind that speaking club can increase vocabulary mastery.

In reducing misunderstanding, 2 respondents (18.2\%) strongly agree that speaking club can reduce it. The other 8 respondents $(72.7 \%)$ agree. But one respondent $(9.1 \%)$ don't think so. It can be concluded that most students believe that speaking club can reduce misunderstanding in speaking.

Related to the statement number 8 , activities in speaking club can increase self-confidence for the respondents. There are 6 respondents $(54.5 \%)$ and 5 respondents $(45.5 \%)$ who agree and strongly disagree with this. We know that activities in speaking club are effective in increasing confident, especially in speaking skill.

Next, speaking club also impacts the ability of the respondents to exchange relevant ideas because there are 6 respondents $(54.5 \%)$ and 5 respondents $(45.5 \%)$ who agree and strongly disagree with this. No one thinks that speaking club does not impact it.

Based on the statement number 10, we can see that in giving the efficient, speaking exercise, the respondents give various choices. 2 respondents (18.2\%) and 8 respondents $(72.7 \%)$ strongly agree and disagree. The rest, there is only one participant who does not think so $(9.1 \%)$. Most of them believe this statement.

Speaking club also provides supplementary material such as storybooks, language CDs, etc. There are 3 respondents (36.4\%) who disagree with this. On the other hand, there are 2 respondents $(18.2 \%)$ who strongly agree and the other, 6 respondents $(45.5 \%)$ are agree.

For statement number 12, there are 6 respondents (54.5\%) who agree and one respondent $(9.1 \%)$ who strongly disagree, and 4 respondents $(36.4 \%)$ who disagree that speaking club provides sufficiency facilities for them. No one strongly agrees with this statement.

Then, the environment in speaking club can be enjoyed by the respondents. Evident from the result of statement number 13 , there are 3 respondents $(27.3 \%)$ who strongly agree and 8 respondents $(72.7 \%)$ who agree. Actually, the environment of the speaking club gives the influence to support speaking skill for the students.

The last, by joining speaking club, the respondents feel no worries again to make mistakes because 7 respondents $(63.6 \%)$ strongly agree and 4 respondents $(36.4 \%)$ agree with this.

From the explanation above, the researcher can examine whether the research questions of this research were answered or not. The research questions are:

1. What is students' perception about speaking club can improve speaking skill? 
2. What are the challenges and the effects of joining speaking club viewed from students' perception?

The first discussion deals with whether speaking club improves students' speaking ability based on students perception. Based on Kasmalinda's (2012) research finding, she found that the speaking club improves the students' speaking ability because speaking club encourages and motivates them to practice speaking. The results of her research showed that they were more interested in practicing English speaking in the speaking club.

As we can see in the findings, after distributing the questionnaire, the writer found various students' response toward speaking club. Based on the results of the questionnaire, the writer concluded that all of the students had positive reactions toward speaking club. All of them admitted that they felt happy to learn speaking through speaking club that encouraged their willingness to practice speaking English. During the discussion (as one of speaking activities in this club), they showed their enthusiasm to speak in the classroom and they did all the assignments.

For the second research question, the writer found that speaking club can give effects for the students. As mentioned in the questionnaire, one of the effect in joining speaking club is it makes them more confident when they are speaking English. Similarly, the other positive results can be obtained in speaking club.

Heilman (1981) contends that enthusiasm in language study, especially in speaking, is related closely to success. Moreover, they said active class participation is important in all the language skills, especially in speaking. In addition, the important point is that the students feel free to participate and to speak the language. Any measure of skill is impossible without practice. Therefore, the students need a lot of opportunities to practice the language.

Based on the research findings and the discussion, it can be concluded that speaking club improves the students' speaking ability especially in using the appropriate vocabulary, building their critical thinking and being brave to tell the ideas they have in their mind and encouraging them to communicate with others actively. As seen in the table above that joining speaking club can give effect good improvement for students. They have improvement in pronunciation, vocabulary, and fluency in speaking English. Even they also felt confident in speaking English without afraid of making mistakes. While the challenges that they have in joining speaking club is that the lectures or faculty less provide sufficiency facilities to support them to practice speaking English.

\section{CONCLUSION}

From the research findings and the result of questionnaires above, it can be concluded that joining speaking club improves the students' English speaking skill. Most of the students had positive responses towards their joining in speaking club. The students claim that this speaking club is very important and useful for them because by joining English speaking club, they felt that they had improvement in pronunciation, vocabulary, and fluency in speaking English. Even they also felt confident in speaking English without being afraid of making mistakes. The activities provided by English speaking club can encourage them to be more motivated and more spirited to practice speaking English with their friends in that club.

After analyzing the data gotten from the questionnaire, the writer would like to present suggestions, as follow:

1. The lecturers or faculty should provide sufficiency in speaking club to support them to always practice in their club. In addition, the lectures should give guidance or recommendation for other students to join English speaking club. Because by joining speaking club, students can improve their vocabulary, pronunciation, and confidence in speaking English without being afraid of making mistakes.

2. The lecturers of speaking club should give the students an interesting topic and provide sufficiency facilities in speaking activity learning. So, the students will be more interested in speaking practice.

\section{REFERENCES}

[1] Abbaspour, Faezah. 2016. Speaking Competence and Its Components: A Review of Literature. Amol Iran: International Journal of Research In Linguistic, Language Teaching And Testing. Vol.1 Issue 4, Pp.144-15.

[2] AgungWijaya, Surya. 2016. The Use of Teaching British Parliamentary Debate through Android Application, Video, and Powerpoint Presentation to Improve The Students' Speaking Skills. Salatiga: Register Journal. Vol 9, No 2.

[3] Azizah, Ismi. 2016. An Analysis of Student Difficulties in Speaking English: A Case Study at Eleventh Grade Students of MA Al-Muslimun NW in Tegal Academic Year 2015-2016. Mataram: University Of Mataram.

[4] Baihaqi. 2016. The Influence of Speaking Club in Improving Students Speaking Ability. Banda Aceh: Ar-Raniry State Islamic University.

[5] FitriAnggreni, Selvia. 2016. The Effect of English Club on Students' Speaking Ability at Smpn 2 LembahGumanti. Sumatra Barat: English Departement, STKIP SUMBAR.

[6] Mistar, Junaidi; UmamahAtik. 2014. Strategies of Learning Speaking Skill by Indonesia Learners of English and Their Contribution to Speaking Proficiency. Malang: TEFLIN Journal. Volume 25, Number 2.

[7] NovitaAswary, Devi. 2014. A Study of Students Problem in Learning Speaking English at The Second Grade of SMP Negeri 1 Talaga. Cirebon: Nurjati State Institute For Islamic Studies.

[8] Setyarini, Sri; Bukhori M, Ahmad;Dkk. 2018. Thinking Critically While Storytelling: Improving Childrens' HOTS and English Oral Competence. Bandung: Indonesian Journal Of Applied Linguistics. Vol 8, No. 1.

[9] Tsou, Wenli. Spring 2005. Improving Speaking Skills Through Instructions in Oral Classroom Participation. Taiwan: National University of Tainan. Foreign Language Annals - Vol 38, No 1.

[10] Wahyuni; Basri, Hasan; Mashuri. 2014. The Influence of English Day Towards Students' Speaking Skill at The Eighth Graders. Palu: EJournal of English Language Teaching Society (ELTS). Vol 2, No 4.

[11] Yuliandasari, Aida; Kusriandi, Wendi. 2015. Students' Perception on English Club Extracurricular in Speaking Practices at Madrasah. Unswagati Cirebon: DepartementOf English Education. ELT Perspective 3(2).

[12] Zuhriyah, Mukminatus, Dkk. 2018. The Influence of Students' Creativity to Construct Sentences Toward Their Speaking Skill. Salatiga: Register Journal. Vol 11, No 1. 